\title{
Al を活用したトレーニングメニュー提供の可能性
}

山田実

(筑波大学人間系)

一般的に，高齢者に運動指導を行う場合には，(1)集団 に対して同じ運動プログラムを同時に指導する, (2)個別 に応じた運動プログラムを提供する，という 2 通りで実 施されることが多い.しかし，それぞれにメリット・デ メリットがあり，例えば，(1)の集団で同じ運動プログラ ムを提供する場合には, 対象が高齢者であることからそ れぞれの機能レベルの差が大きく, その運動種や負荷量, 難易度の設定など苦慮することが多い。一方, (2)の個々 に応じた運動プログラムを提供する場合, その専門性や 煩雑性などとの問題から, セラピストやトレーナーなど の専門家不在の環境下では現実的とは言えない. そのよ うな中で, どのような環境下でも(2)の個別運動プログラ ムの提供の実現を目指し, (A) 高齢者の能力分類のた めのアルゴリズム作成 (パターンメイド型)，（B）セラ ピストによる完全個別フィードバック（オーダーメイド 型）などを実施している。このような個々の状態に応じ たパターンメイドおよびオーダーメイド型の運動プログ
ラムの実施により，身体機能向上効果が得られることを 確認している.

日々蓄積され続ける大量のデータをディープラーニン グや強化学習等を取り入れた人工知能 (AI) を用いて解 析することで，これまでには表面化されることがなかっ た問題や対策が取られるようになっている。運動プログ ラムの提供に際しては, 対象者個々人の機能レベルのみ ならず日々の活動量なども加味したプログラムの提供が 理想的であるが，これまでのアナログ式のプログラム提 供では限界があった。このような点に対し，近年開発が 加速している各種デバイスを適切に活用したデータ収集 を行い, 基本属性や各種身体機能までを考慮した解析を 行うことで, より適切かつ有用な運動プログラムの提供 につながる可能性がある。現時点ではデータが十分に蓄 積されておらず，AIの強みを十分に発揮するに至ってな いが, 今後, 適切にデー夕を収集し続けることで未来予 測も含めた運動プログラムの提供の実現を目指したい.

\section{$\mathrm{Al}$ を活用した次世代デジタルヘルスケアサービスの可能性}

田 㴊 鳴 利

（アレグロスマート株式会社 CEO）
現代の社会問題とされる少子高齢化は, 技術者・医師・ 看護者・データサイエンティスト等の様々な不足を生み 出している. 更に, 新しい技術DTXや, リアルワールド の世界が認知され始め, データの使い方が注目されてい る、デー夕を上手に活用していくことが，人が快適に， 安心して暮らしていく礎になることは間違いない. 技術 の進化に対応して，データに隠れている価值を，様々な 角度から分析・解析ができるデータ・イノベーションプ ラットホームが必要になってくる。医療に限定すれば, 組織を超えて, 知識と知恵とお互いのコミュニケーショ ンの連携ができる，医療データ・イノベーションプラッ トホームというべきだろう。個々の病院の臨床試験デー 夕, 個々の病院の電子カルテデータ, 病内の検査データ であるレントゲン, CT, 遺伝子解析データ, 個々の人間 ドックのデータ, 日常生活における何種かのウェラブル デバイスからの心拍数, 睡眠時間, 活動時間, 血圧, ス トレス值, 個人データである身長・体重のデータや, 運 動量值等々のデータ, 環境センサーの照度, 風速, 風向,
雨量, 温度, 湿度のデータ, 勤務先での活動デー夕, 職 種デー夕，勤務時間デー夕，人間関係データが繋がって いく. 更に, Big Dataという多量のデータを保存出来る 事で，またその活用が期待できるようになった。 ご存知 の通り AI は, 精度をあげる上で多量のデータが必要で あり，過去と現在のデータを照らし合わすことも必要で ある。しかし, 過去のデータのほとんどは, 色々なフォー マットで保存されており, 手付かずのまま置かれている ケースが多い. 我々は, 過去の様々な形で保存されたデー 夕を共通化し, 整理し, 保存している. 文字デー夕, 数 值デー夕，画像デー夕等, データの夕イプや意味が違っ ていたもの含めてである。その多種多様の大量なデー夕 を活用するためには, 自動分析・解析, 予測を行える AI が必要であり，未病対策の技術として役立てる事ができ ると考えている。未病対策だけに留まらず，病院との連 携により，担当医師へのデータの提供，救急車への連携 を自動で行い，搬送の効率化など，様々なことに役立て ることができるということについて述べる。 